\title{
Traumatic episodes experienced during the genocide period in Rwanda influence life circumstances in young men and women 17 years later
}

Lawrence Rugema ${ }^{1,3^{*}}$, Ingrid Mogren ${ }^{2}$, Joseph Ntaganira ${ }^{1}$ and Krantz Gunilla ${ }^{3}$

\begin{abstract}
Background: During Rwanda's genocide period in 1994, about 800,000 people were killed. People were murdered, raped and seriously injured. This retrospective study investigated prevalence and frequency of traumatic episodes and associated psychosocial effects in young adults in Rwanda over the lifetime, during the genocide period and in the past three years.

Methods: This is a cross-sectional population-based study conducted among men and women, aged 20 to 35 years, residing in the Southern province of Rwanda. The study population, randomly selected in a multi stage procedure, included 477 females and 440 males. Data collection was performed through individual interviewing with a structured questionnaire during the period December 2011- January 2012. The Harvard Trauma Questionnaire was used to assess traumatic episodes. All data was sex-disaggregated. Differences between groups were measured by chi square and Fischer's exact test. Associations with socio-demographic and psychosocial factors were estimated by use of odds ratios with $95 \%$ confidence intervals in bi- and multivariate analyses.

Results: The participants in this study were 3 to 18 years of age in 1994, the year of the genocide. Our sample size was 917 participants, 440 men and 477 women. Women were to a higher extent exposed to traumatic episodes than men during their lifetime, $83.6 \%(n=399)$ and $73.4 \%(n=323)$, respectively. During the genocide period, $37.5 \%$ of the men/boys and $35.4 \%$ of the women/girls reported such episodes while in the past three years (2009-2011) $25.0 \%$ of the men and $23.1 \%$ of the women did. Women were more exposed to episodes related to physical and sexual violence, while men were exposed to imprisonment, kidnapping and mass killings. Victims of such violence during the genocide period were 17 years later less educated although married (men OR 1.47; 0.98-2.19; women OR 1.54; 1.03-2.30), without children (men OR 1.59; 1.08-2.36; women OR 1.86; 1.11-3.08) and living under extremely poor circumstances.

Conclusion: The participants in this population-based study witnessed or experienced serious traumatic episodes during the genocide, which influenced their life circumstances 17 years later. Such traumatic episodes are however still taking place. The reasons for this need further investigation.
\end{abstract}

Keywords: Traumatic episodes, Genocide, Long-term effects, Young adults, Harvard Trauma Questionnaire, Rwanda

\footnotetext{
* Correspondence: Irugema@nursph.org

'Department of Community Health, School of Public health, National

University of Rwanda, Kigali, Rwanda

${ }^{3}$ Department of Public Health and Community Medicine, The Sahlgrenska

Academy at Gothenburg University, Gothenburg, Sweden

Full list of author information is available at the end of the article
} 


\section{Background}

Extermination of a large part of the Tutsi minority ethnic group by the Hutu extremists is what characterized Rwanda during the spring of 1994, where in a three months' period at least 800,000 people were massacred primarily by other civilians [1-3].

Most people were killed in their local communities by perpetrators who were known to the victims. Women were systematically raped and some later hatched to death, and children were also victims of such violence. Tens of thousands of women were intentionally infected with HIV, sexually humiliated and mutilated by the attackers [4-7]. Two million people fled their homes and became refugees in neighbouring countries [8]. It tore Rwandans apart despite having a common history and speaking the same language and now remains as a difficult past [9].

The immediate effects of the genocide on children were investigated in a study conducted in 1995, among 30 primary and secondary schools in various communes in Rwanda. Over $90 \%$ of the respondents witnessed killings and their lives were threatened, one third lost closer family members or witnessed rape as well as mutilation and 15\% hid under dead bodies for protection [10]. Another study, conducted 13 months after the genocide, revealed inability of many of the young victims to concentrate due to what they had witnessed [11].

The government of Rwanda established a system of community-based conflict resolution courts in 2005, known as Gacaca. These community courts were put in place to locally try thousands of genocide related suspects for having taken part in the massacres [12-14]. The Gacaca hearings allowed community members to participate as witnesses. The month of April is the Genocide Memorial Period when a number of commemoration gatherings are held and testimonies given of what survivors went through, resulting in rewinding of psychological trauma and potential reprisals [15].

Although the legacy of the genocide has become part of life for Rwandans, including those who were children at the time, Rwanda has developed into a society with economic growth and social development, and where community structures allow collective civic engagement to ensure good governance and social protection of the population [16].

Enrolment in basic primary education is currently about $96 \%$ with a somewhat higher enrolment for girls than for boys (97.5 and 94.3\%). These figures are the highest ever in the history of the country, but with a dropout rate of $11.4 \%$, i.e. children do not finish primary education [17]. Currently $77 \%$ of adult females and $82 \%$ of adult males are considered literate in Rwanda [18].

The post genocide Rwanda is characterized by women's empowerment. In 1999, property laws were amended and since then women have the right to inherit land and other valuable assets [19]. The Rwanda constitution legislates that at least $30 \%$ of senators should be women [20]. As a consequence, several leadership positions are occupied by women. Currently, $56 \%$ of the parliamentarians are women, which positions Rwanda's parliament as the world's leading country in this respect [21].

In this particular study, the prevalence and frequency of traumatic episodes experienced by young adults, 20-35 years of age, were explored during lifetime, the genocide period and in the past three years. Possible associations with psychosocial factors were further investigated for long-term effects. This study is part of a larger project on violence and traumatic episodes, mental health and barriers to care, The Rwandan Violence, Mental Health and Barriers to Care project (RwVMHBC- project).

\section{Methods}

This cross-sectional population-based study took place in the Southern province of Rwanda and included adult men and women, aged 20-35 years. This region is mainly rural but includes also an urban city, Butare. As mental health was the overall RwVMHBC project outcome, the sample size was calculated based on the prevalence of depression (20\%) in men and women in Rwanda [22]. To detect a 1.5 fold risk increase of depression, with $80 \%$ probability, the sample size was estimated to 815 people after taking non-responders into consideration. As the prevalence of depression in men is generally lower than in women [22], it was decided to increase the sample size to 900 . A total population of 917 individuals was finally included in the study, 440 (48\%) men and 477 (52\%) women. The data was collected in the period December 2011 to January 2012.

\section{Data collection}

A two-stage random selection of participants was done by use of the nation-wide demographic health survey procedure to identify households for inclusion in the survey. Rwanda is divided into four provinces and the Southern Province with an estimated population of 2.226.000 was chosen as it includes rural and urban areas. It is divided into eight districts. A complete list of all villages and households was made available from the National Institute of Statistics of Rwanda (NISR).

Out of the total number of 3512 villages in the eight districts, 35 Primary Sampling Units (villages) were selected, representing $10 \%$ of the total number of villages in the province. In each district, the number of villages selected was proportional to the total number of villages, using Epi-Info to generate random numbers. The number of households for inclusion in each village was then proportional to the total number of households in each selected village. 
One young adult was selected from the first household closest to the centre of the village. If the first eligible participant was a female, the next eligible participant was to be a male. Only one interview was conducted with an eligible individual in each household for ethical and security reasons. If there was no eligible person living in the household, the closest household was approached. The rationale behind choosing a neighbouring household was that living conditions would possibly be similar to that of the primary selected household. If the eligible individual was not at home, the interviewer returned later on, up to three times on different days to interview the selected person. The final sample consisted of 917 participants, 440 men and 477 women, aged 20-35 years, all permanent residents of Rwanda at present. Only two people refused participation in the study, and the final response rate was 99.8\%.

A questionnaire was developed based on previously validated instruments. It contained items on traumatic episodes, physical and mental health and access barriers to care, and was translated into Kinyarwanda and back translated by a professional language translator.

Traumatic episodes were measured by a revised version of the Harvard Trauma Questionnaire, an instrument that has been used in several other post conflict settings and validated in different populations and languages [23,24]. The authors state that with careful adaptation to a cultural setting, the scale can be used to assess trauma in nonwestern populations $[25,26]$. Of the 34 items included, directly related to trauma experience, 16 were chosen as appropriate for this study. These items were selected and agreed upon by the Rwandan researchers (JN, LR) in discussions with the principal investigator (GK).

A team of 13 clinical psychologists (seven females and six males), experienced in conducting data collection for the School of Public Health, National University of Rwanda were trained for two days to manage the data collection tools. During the two-days training, the instrument was reviewed. A one day pre-testing exercise was carried out and the questionnaire was revised accordingly. Female participants were interviewed by women, and male participants by men to minimize information concealment. The data collection was supervised by persons with previous experience of similar studies (LR, first author and a team supervisor at School of Public Health).

The data collection was implemented by two teams, each consisting of one supervisor and six to seven interviewers. Each team supervisor was responsible for overseeing the work of the team by identifying the households to be visited, observing interviews, managing questionnaires and for re-interviewing a selected number of participants for reliability purposes. Data was entered by four experienced personnel, who draw their expertise from entering DHS data in Rwanda. The supervisor (first author, LR) crossed-checked on a daily basis the quality of data entered and if there were any anomalies, these were corrected immediately.

\section{Dependent variables}

The items on traumatic episodes (Harvard Trauma Questionnaire) [23] ask about having witnessed or own experience of various traumatic episodes. Response categories are 'yes' and 'no' with a follow-up question on age at event. Items were treated individually but for further analyses, a summary index was made for episodes during lifetime, the genocide period and the past three years, dichotomized into having experienced at least one traumatic episode as the exposed, and no such exposure constituted the reference category.

\section{Independent variables}

Socio-demographic and psychosocial variables from the Rwanda Demographic and Health survey 2010, were used with slight adjustments. Age was categorized into three groups 20-24, $25-29$ and 30-35 years of age and for further analyses, dichotomized with the youngest age group as the reference category. Marital status was classified into married or cohabiting as opposed to being widowed, divorced or single.

Number of children was divided into having no children, 1-3 children, and >3 children, later dichotomized into having or not having children with the latter as the reference category. Educational level was divided into three groups: secondary school or university level, completed primary school or vocational training, and incomplete primary school; then dichotomized with the highest educational level as the reference category. Ever been to school was categorized into 'yes' and 'no' with 'yes' being the reference category. Employment status was divided into three groups, i.e. full time paid employment, irregular or seasonal work and no employment. Personal income per month was categorized into three groups: $>35,000$ Rwandan Franc (RWF), 17,000 RWF - 35,000 RWF, and $<17500$ RWF. For analysis purposes it was dichotomized at the level of 17,500 RWF (equivalent to 30 USD). Source of income was divided into four categories: salary, pension, disability grant and no income; in the further analyses any source of income was made the reference category. The social support measure consisted of seven items inquiring about support from a relative or a friend when needed (share food, share housing, assisted when ill, borrow money, guidance on how to improve present life situation, support when in personal problems), belonging to any association. A dichotomised variable was created where a 'no' response to all items was categorized as poor social support and at least one 'yes' response was categorized as having improved social support. 
Living standard comprised house type (modern house or shack), toilet facility (flushing or latrine), electricity in the house (yes or no), cooking fuel (paraffin or firewood/ dung), and water source (tap water or surface water). The second category of these variables was considered as the negative exposure. A summary variable was constructed where improved standard was equal to having at least one of the improved standards while having none of the improved standards characterised poor living standard.

The Assets in the household variable was based on possession of any of the assets (radio, television set, mobile phone, computer, refrigerator, motorcycle, bicycle or car) in the household.

A summary variable was created by adding up the number of assets owned in the household. Not being in possession of any of the assets formed the exposure category.

Household monthly income was dichotomised in the same way as personal income, described above.

\section{Statistical methods}

Prevalence was calculated for each specified traumatic episode and a summary variable was constructed for three time periods: lifetime, the genocide period and past three years. The traumatic episodes related to the genocide period (1994) included all cases reported in the period 1994 \pm 1 year to take care of recall bias of the exact age of exposure. This procedure was found important as age at episode was inquired about and not the exact timing (year) of each episode. As 17 years have elapsed since the genocide period in 1994 and some of the participants were really young then (from 3 years of age), it is plausible that some were unaware of their exact age, as evidenced in other studies [27]. Traumatic episodes during life time relate to experience of any of the items inquired about during any point in life and past three years included all traumatic episodes experienced in the years 2009-2011.

Data was sex-disaggregated and statistical significance for difference between groups was obtained by use of Pearson's chi square test and Fischer's exact test.

Associations between traumatic episodes during lifetime and in 1994 \pm 1 year and socio-demographic and psychosocial variables were calculated by use of odds ratios (OR) with $95 \%$ confidence intervals $(95 \% \mathrm{CI})$. Although this is a cross-sectional study, with all data collected at the same point in time, the exposure to traumatic episodes during the genocide period took place about 17 years earlier than measures of current socio-demographic and psychosocial circumstances, which makes it possible to draw cautious conclusions on long-term effects of the trauma. Multivariate logistic regression analyses were also performed, controlling for age, number of children, education and income as statistically significant in the bivariate analyses, or close to, for both men and women. Data were entered into SPSS version 19 (SPSS v 19.0; IBM SPSS Inc.) and this software was used for all statistical calculations.

\section{Definitions}

The variable traumatic episodes was here defined as trauma and torture related to mass violence [26].

Young adults are defined as men and women aged 2035 years of age, as is customary in Rwanda.

\section{Ethical considerations}

Permission and ethical clearance was sought from the Rwanda National Ethics Committee. Approval was given with the reference number FWA Assurance No. 00001973, IRB 00001497 of IORG0001100.

Respondents were informed orally and in writing about their possibility to withdraw from the study at any stage. Participants were further informed that anonymity and confidentiality would be kept at all stages of the research project. The structured interviews following the questionnaire were initiated after a written informed consent was granted by the respondents. All interviews were performed in complete privacy, either outside the house or inside, or in a nearby private location, depending on the choice of the study participant. All personal identity information noted in the questionnaires (village, cluster) was never entered into the data analysis tool.

\section{Results}

\section{Respondents' characteristics}

Of the 440 men and 477 women participating in the study, $80 \%$ lived in rural areas and $20 \%$ in an urban environment (Table 1). The great majority were generally poor with only few having secondary or university education (men 13.3\%, women 17.0\%), few were employed and the household income was generally low. Women to a higher extent than men reported not having completed primary school (women $64.4 \%$, men $58.7 \%$ ). The majority of the households had 1-3 three children and women were generally poorer than men in terms of assets and to a lesser extent earned an income.

Housing standard was higher for men than for women with more women living in a shack type of housing (Table 2). Access to safe water also indicated a real difference in standard of living between men $(77 \%, \mathrm{n}=338)$ and women $(44 \%, n=208)$. Among household assets, a radio was possessed more than any other item by both women and men (60.1\% women, $68.2 \%$ men), while bicycles were more often owned by men, however more women than men were in possession of a mobile phone.

These data point at the homogeneity of the population and communities in terms of living standard and assets in the households. Most households neither owed a refrigerator nor a car, television or a computer (Table 2). 
Table 1 Socio-demographic and psychosocial factors for men and women with p-values for difference between men and women

\begin{tabular}{|c|c|c|c|c|c|}
\hline \multirow{2}{*}{$\begin{array}{l}\text { Variables } \\
\text { Respondent's characteristics }\end{array}$} & \multicolumn{2}{|c|}{ Men } & \multicolumn{2}{|c|}{ Women } & \multirow[t]{2}{*}{$\mathrm{p}$-value } \\
\hline & $n$ & $\%$ & $n$ & $\%$ & \\
\hline \multicolumn{6}{|l|}{ Age groups $(\mathrm{N}=908)$} \\
\hline $20-24$ & 148 & 33.8 & 127 & 27.0 & .050 \\
\hline $25-29$ & 144 & 32.9 & 156 & 33.2 & \\
\hline $30-35$ & 146 & 33.3 & 187 & 39.8 & \\
\hline \multicolumn{6}{|l|}{ Marital status $(\mathrm{N}=912)$} \\
\hline Married and cohabiting & 236 & 53.8 & 342 & 72.3 & $<0.001$ \\
\hline Widowed and divorced & 2 & 0.5 & 33 & 7.0 & \\
\hline Single & 201 & 45.8 & 98 & 20.7 & \\
\hline \multicolumn{6}{|l|}{ Number of children $(\mathrm{N}=915)$} \\
\hline No children & 211 & 48.1 & 96 & 20.2 & $<0.001$ \\
\hline 1-3 children & 192 & 43.7 & 275 & 57.8 & \\
\hline$>3$ children & 36 & 8.2 & 105 & 22.1 & \\
\hline \multicolumn{6}{|l|}{ Level of education $(\mathrm{N}=768)$} \\
\hline Secondary school or University level & 50 & 13.3 & 67 & 17.0 & .006 \\
\hline Complete primary or vocational level & 105 & 28.0 & 73 & 18.6 & \\
\hline Incomplete primary & 220 & 58.7 & 253 & 64.4 & \\
\hline \multicolumn{6}{|l|}{ Ever been to school $(\mathrm{N}=915)$} \\
\hline Yes & 369 & 84.2 & 393 & 82.4 & .479 \\
\hline No & 69 & 15.8 & 84 & 17.6 & \\
\hline
\end{tabular}

Employment status ( $\mathrm{N}=913)$

\begin{tabular}{|c|c|c|c|c|c|}
\hline Full time paid employment & 55 & 12.5 & 29 & 6.1 & $<0.001$ \\
\hline Irregular or seasonal work & 33 & 7.5 & 17 & 3.6 & \\
\hline No employment & 348 & 79.1 & 431 & 90.4 & \\
\hline \multicolumn{6}{|c|}{ Personal income per month $(\mathrm{N}=912)$} \\
\hline More than $35,000 \mathrm{RF}$ & 19 & 4.3 & 11 & 2.3 & .005 \\
\hline $17,500-35,000 \mathrm{RF}$ & 36 & 8.2 & 19 & 4.0 & \\
\hline Less than $17,500 \mathrm{RF}$ & 382 & 86.8 & 445 & 93.3 & \\
\hline
\end{tabular}

Source of income $(\mathrm{N}=903)$

\begin{tabular}{lccccc}
\hline Salary & 38 & 8.7 & 9 & 1.9 & $<0.001$ \\
\hline Pension, disability grant or other & 54 & 12.3 & 34 & 7.3 & \\
\hline No income & 347 & 79.0 & 421 & 90.7 & \\
\hline Social support $(\mathbf{N}=\mathbf{9 1 7})$ & & & & & \\
\hline Improved & 77 & 17.5 & 63 & 13.2 & .081 \\
\hline Poor & 363 & 82.5 & 414 & 86.8 &
\end{tabular}

Household characteristics

Household monthly income $(\mathrm{N}=\mathbf{8 8 3})$

\begin{tabular}{llllll}
\hline $17,500 \mathrm{RF}$ or more & 86 & 20.5 & 103 & 22.2 & .566 \\
\hline Less than $17,500 \mathrm{RF}$ & 333 & 79.5 & 361 & 77.8 & \\
\hline
\end{tabular}

$\mathrm{N}=917,440$ men and 477 women.

\section{Exposure to traumatic episodes}

Of the total population, $78.7 \%$ had experienced at least one traumatic episode in their life time (Table 3). Women were to a higher extent exposed than men, $83.6 \% \quad(\mathrm{n}=399)$ and $73.4 \% \quad(\mathrm{n}=323)$, respectively
(Table 4). During the genocide period, $37.5 \%$ of the men and $35.4 \%$ of the women reported such episodes while in the past three years (2009-2011) 25\% of the men and $23 \%$ of the women reported experience of traumatizing episodes.

\section{Lifetime occurrence of traumatic episodes}

Almost half of the study population had experienced imprisonment of a close family member and one third had witnessed a traumatic event to a loved one in their lifetime (Table 1). Being a refugee, forced to flee from home to escape danger/persecution was experienced by $24.9 \%$ and about the same proportion had experienced a murder or unnatural death of a family member or a friend (24.3\%). Of the total population, $17.6 \%$ had to witness atrocities such as mass killings and mutilated bodies.

Gender differences showed that while women were more exposed to traumatic episodes related to physical and sexual violence, such as rape, forced to have sex for benefits, witnessing violence between family members and also to have witnessed sexual violence against a family member by a stranger, men were to a greater extent exposed to imprisonment, kidnapping, mass killings or were badly injured (Table 4 ). This explains partly what is seen in the Rwandan society today, i.e. a high number of widows after loss of their husbands during the genocide [28].

\section{The genocide period}

Given the circumstances of the 1994 period, some of the traumatic episodes were especially prevalent, as could be expected (Table 1). Being a refugee and forced to flee from home affected $13.1 \%$ of the total population but corresponded to $52.9 \%$ of the total number of individuals that experienced this particular episode. Further, we found that having to witness atrocities such as mass killings and mutilated bodies mainly happened during this period (10.9\% of total population versus $61.7 \%$ within this episode). However, in the case of experiencing murder or the unnatural death of a family member or a friend, a significant proportion happened in this period (9.2\% versus $37.7 \%$ ) but it seems the majority of such episodes took place outside of the genocide period. This was also true for imprisonment of a close family member $(8.1 \%$ versus $16.3 \%)$.

More women than men had the experience of witnessing somebody being badly injured or killed, $7.5 \%$ compared to $3.2 \%$. Yet, more men $(14.1 \%, \mathrm{n}=62)$ than women $(8.0 \%, \mathrm{n}=38)$ had witnessed atrocities such as mass killings and mutilated bodies (Table 4).

\section{Past three years (2009-2011)}

A somewhat worrying finding was that having experienced a murder or unnatural death of a family member 
Table 2 Living standard and Assets in the household, men and women

\begin{tabular}{|c|c|c|c|c|c|}
\hline \multirow{2}{*}{$\begin{array}{l}\text { Variable } \\
\text { Living standard characteristics }\end{array}$} & \multicolumn{2}{|c|}{ Men } & \multicolumn{2}{|c|}{ Women } & \multirow[t]{2}{*}{ p-value } \\
\hline & $\mathrm{n}$ & $\%$ & $n$ & $\%$ & \\
\hline \multicolumn{6}{|l|}{ House type $(\mathrm{N}=915)$} \\
\hline $\begin{array}{l}\text { Combined building, flat, modern house, } \\
\text { maisonette }\end{array}$ & 189 & 43.1 & 175 & 36.8 & .058 \\
\hline Shack & 250 & 56.9 & 301 & 63.2 & \\
\hline \multicolumn{6}{|l|}{ Toilet facility $(\mathrm{N}=910)$} \\
\hline Flushed, improved latrine & 14 & 3.2 & 10 & 2.1 & .071 \\
\hline Latrine or no toilet & 422 & 95.6 & 464 & 97.3 & \\
\hline \multicolumn{6}{|l|}{ Electricity in the household $(\mathrm{N}=914)$} \\
\hline Yes & 39 & 8.9 & 68 & 14.3 & .103 \\
\hline No & 400 & 90.9 & 407 & 85.3 & \\
\hline \multicolumn{6}{|l|}{ Cooking fuel $(\mathrm{N}=914)$} \\
\hline Kerosene, paraffin and other fuels & 37 & 8.4 & 41 & 8.6 & .896 \\
\hline Firewood and dung & 403 & 91.6 & 433 & 90.8 & \\
\hline \multicolumn{6}{|l|}{ Water source $(\mathrm{N}=912)$} \\
\hline Tap water, borehole water & 338 & 76.8 & 208 & 43.6 & $<0.001$ \\
\hline Surface water & 101 & 23.0 & 265 & 55.6 & \\
\hline
\end{tabular}

\begin{tabular}{|c|c|c|c|c|c|}
\hline $\begin{array}{l}\text { Living standards, summary } \\
\text { measure }(N=917)\end{array}$ & & & & & \\
\hline $\begin{array}{l}\text { Improved (at least one of the higher } \\
\text { standard items) }\end{array}$ & 366 & 83.2 & 305 & 63.9 & $<0,001$ \\
\hline $\begin{array}{l}\text { Poor (none of the higher standard } \\
\text { items) }\end{array}$ & 74 & 16.8 & 172 & 36.1 & \\
\hline
\end{tabular}

\begin{tabular}{|c|c|c|c|c|c|}
\hline Asse & & & & & \\
\hline Radi & & & & & \\
\hline Yes & 300 & 68.2 & 286 & 60.1 & .011 \\
\hline No & 140 & 31.8 & 190 & 39.8 & \\
\hline Tele & & & & & \\
\hline Yes & 25 & 5.7 & 30 & 6.3 & .781 \\
\hline No & 415 & 94.3 & 446 & 93.7 & \\
\hline Refri & & & & & \\
\hline Yes & 2 & 0.5 & 6 & 1.3 & .290 \\
\hline No & 437 & 99.5 & 470 & 98.7 & \\
\hline Bicy & & & & & \\
\hline Yes & 87 & 19.8 & 58 & 12.2 & .002 \\
\hline No & 352 & 80.2 & 418 & 87.8 & \\
\hline Mot & & & & & \\
\hline Yes & 4 & 0.9 & 13 & 2.7 & .050 \\
\hline No & 435 & 99.1 & 463 & 97.3 & \\
\hline Car & & & & & \\
\hline Yes & 3 & 0.7 & 9 & 1.9 & .147 \\
\hline No & 436 & 99.3 & 467 & 98.1 & \\
\hline Mob & & & & & \\
\hline Yes & 122 & 27.8 & 160 & 33.6 & .062 \\
\hline No & 317 & 72.2 & 316 & 66.4 & \\
\hline
\end{tabular}

Table 2 Living standard and Assets in the household, men and women (Continued)

\begin{tabular}{|c|c|c|c|c|c|}
\hline Computer (914) & & & & & \\
\hline Yes & 3 & 0.7 & 10 & 2.1 & .094 \\
\hline No & 435 & 99.3 & 466 & 97.9 & \\
\hline \multicolumn{6}{|l|}{$\begin{array}{l}\text { Assets in household, summary } \\
\text { measure }(N=917)\end{array}$} \\
\hline $\begin{array}{l}\text { Improved (At least one of the higher } \\
\text { standard items) }\end{array}$ & 323 & 73.4 & 331 & 69.4 & .189 \\
\hline $\begin{array}{l}\text { Poor (None of the higher } \\
\text { standard items) }\end{array}$ & 117 & 26.6 & 146 & 30.6 & \\
\hline
\end{tabular}

$\mathrm{N}=917,440$ men and 477 women. $p$-values for difference between men and women.

still happened in the period 2009-2011. In the past three years, $2.1 \%$ of the total population reported such experience, men to a somewhat higher proportion than women. Witnessing physical or sexual violence against a family member was a somewhat more common experience in the past three years than in the genocide period (Table 3). The most frequent exposures in both men and women were however related to imprisonment of a close family member (men 5.9\%; women 6.1\%) and having witnessed a traumatic episode directed at a loved one (men 6.6\%; women 6.3\%).

Finally, the accumulated number of the various traumatic episodes during lifetime is displayed in Figure 1. A higher proportion of women had experienced any traumatic exposure. Women also dominated in the highest range, i.e. 7-12 different exposures.

\section{Traumatic episodes and socio-demographic and psychosocial factors}

Associations between traumatic episodes experienced in the genocide period, and socio-demographic and psychosocial factors mirroring current life circumstances were investigated in bi-variate analyses (Table 5 ). The statistically significant associations hereby illustrate the possible effects of having experienced traumatic episodes about 17 years earlier.

Men exposed during the genocide period belonged mainly to the higher age group, they were less likely to have children (OR 1.59; 95\% CI 1.08-2.36), although married to a woman of about the same age (OR 1.93; 1.12-3.30). The majority had attended school, but our findings also suggest inability to complete primary school, however not statistically significant (OR 1.47; 0.98-2.19). The exposed men were further at a somewhat elevated risk of earning a low income (OR 1.56; 0.89-2.77) than unexposed men, but this was not a statistically significant finding.

Exposed women were more often married but less likely to have any children (OR 1.86; 1.11-3.08), further to be low educated (OR 1.54; 1.03-2.30) and not 
Table 3 Prevalence of Traumatic events among men and women 20-35 years of age in different time periods

\begin{tabular}{|c|c|c|c|c|c|c|c|c|}
\hline \multirow[t]{2}{*}{ Traumatic events } & \multicolumn{2}{|c|}{$\begin{array}{l}\text { Life time prevalence } \\
\quad(1976-2011)\end{array}$} & \multicolumn{3}{|c|}{$\begin{array}{c}\text { Prevalence in } \\
1994+/-1 \mathrm{yr}^{\wedge} \\
\text { (genocide period) }\end{array}$} & \multicolumn{3}{|c|}{$\begin{array}{l}\text { Prevalence in the past } \\
3 \text { years }(2009-2011)\end{array}$} \\
\hline & $\mathbf{N}$ & $\% *$ & $\mathbf{N}$ & $\% *$ & $\% * *$ & $\mathbf{N}$ & $\% *$ & $\% * *$ \\
\hline 1. Have you been imprisoned, kidnapped, held captive & 94 & 10.3 & 8 & 0.9 & 8.7 & 27 & 2.9 & 28.7 \\
\hline 2. Been a refugee, forced to flee from your home to escape danger/persecution & 228 & 24.9 & 120 & 13.1 & 52.9 & 9 & 1.0 & 3.9 \\
\hline 3. Experienced forced separation from family members & 54 & 5.9 & 18 & 2.0 & 33.3 & 3 & 0.3 & 5.6 \\
\hline 4. Experienced a life-threatening injury & 133 & 14.5 & 29 & 3.2 & 21.8 & 19 & 2.1 & 14.3 \\
\hline 5. Experienced a murder or unnatural death of a family member or a friend & 223 & 24.3 & 84 & 9.2 & 37.7 & 19 & 2.1 & 8.5 \\
\hline 6. Been robbed, mugged, threatened with a weapon & 157 & 17.1 & 31 & 3.4 & 19.9 & 30 & 3.3 & 19.1 \\
\hline 7. Experienced imprisonment of close family member & 454 & 49.6 & 74 & 8.1 & 16.3 & 55 & 6.0 & 12.1 \\
\hline 8. Witnessed a traumatic event to a loved one & 306 & 33.4 & 41 & 4.5 & 13.4 & 59 & 6.4 & 19.3 \\
\hline 9. Ever been raped by a stranger & 22 & 2.4 & 2 & 0.2 & 8.7 & 1 & 0.1 & 4.5 \\
\hline 10. Ever felt forced to have sex in exchange of money or other benefits & 31 & 3.4 & 1 & 0.1 & 3.2 & 5 & 0.5 & 16.1 \\
\hline 11. Witnessed repeated violence between family members & 74 & 8.1 & 13 & 1.4 & 17.6 & 11 & 1.2 & 14.9 \\
\hline $\begin{array}{l}\text { 12. Witnessed physical or sexual violence against a family member by someone } \\
\text { outside of the family }\end{array}$ & 54 & 5.9 & 9 & 1.0 & 16.7 & 11 & 1.2 & 20.4 \\
\hline 13. Witnessed someone being badly injured or killed & 131 & 14.3 & 50 & 5.5 & 38.5 & 10 & 1.1 & 7.6 \\
\hline 14. Witnessed atrocities, e.g. mass killings mutilated bodies & 161 & 17.6 & 100 & 10.9 & 61.7 & 5 & 0.5 & 3.1 \\
\hline 15. Been in a combat situation & 114 & 12.4 & 32 & 3.5 & 27.8 & 20 & 2.2 & 17.5 \\
\hline 16. Other life threatening/disturbing event & 157 & 17.1 & 58 & 6.3 & 37.4 & 20 & 2.2 & 12.7 \\
\hline Summary measure of all traumatic events & 722 & 78.7 & 334 & 36.4 & 46.3 & 220 & 24.0 & 30.5 \\
\hline
\end{tabular}

*Percent of total number of cases.

**Percent of cases of respective act.

$\wedge$ The number of events was calculated from reported age of participant at event and recoded into year 1994.

Total population, $\mathrm{N}=917$.

employed (OR $2.15 ; 1.17-3.97)$, with a very low or no income (OR 2.57; 1.22-5.44) but married to someone with complete primary education or higher levels when compared to unexposed women.

These findings for the genocide period were adjusted for in logistic regression analyses controlling for age, number of children, education and income, resulting in minor changes of estimates. Main changes for men were that having no children lost its statistical significance (OR 1.36; 0.85-2.17). For women, only low educational achievement lost its statistical significance (OR 1.46; 0.95-2.24) (not in Table).

For life time exposure to traumatic episodes and sociodemographic and psychosocial factors, no statistically significant associations were found for men (not in Table). For women, there were statistically significant crude associations with not being employed but on a small pension or disability grant, with improved social support, but still with household income being low (not in Table).

\section{Discussion}

This study investigated traumatic episodes among young adults in the Southern province of Rwanda, where life circumstances were found to be similar between households. The majority of the participants were living under somewhat improved housing conditions while about one quarter were in very poor circumstances, with few assets in the household. However, the possession of a mobile phone was the most common asset in a household after a radio and more commonly owned than a refrigerator or a bicycle. In possession of assets, women had less than men, even if more women than men were in possession of a mobile phone, a refrigerator and a computer.

More than one third of the participating men and women recall being exposed to serious traumatic episodes during the genocide but as well during the past three years. Extremely serious exposures, such as being forced to flee the home and to witness mass killings and mutilated bodies mainly occurred during the genocide, with both men and women carrying such experiences.

The violence is to a certain extent still on-going and some of the most commonly occurring episodes in the past three years are of the character that is not expected to occur in peaceful periods, such as being kidnapped or held captive and also violent deaths. The pardoning of perpetrators by the traditional courts (Gacaca) and their subsequent release and return to the community where they lived prior and during the genocide period not only resulted in reconciliation but also unease, fear and even hatred among the survivors, which may explain such ongoing violence [29]. 
Table 4 Men and women exposed to various traumatic episodes during life time, in 1994 and in the past 3 years, presented by sex with $p$-values for sex difference in lifetime estimates

\begin{tabular}{|c|c|c|c|c|c|c|c|c|c|c|c|c|c|}
\hline \multirow[t]{2}{*}{ Traumatic events } & \multicolumn{2}{|c|}{$\begin{array}{c}\text { Men } \\
\text { life time }\end{array}$} & \multicolumn{2}{|c|}{$\begin{array}{l}\text { Women } \\
\text { life time }\end{array}$} & \multirow[t]{2}{*}{$\begin{array}{l}\text { p-values } \\
\text { difference } \\
\text { lifetime }\end{array}$} & \multicolumn{2}{|c|}{$\begin{array}{c}\text { Men } \\
1994+ \\
-1 \text { year }\end{array}$} & \multicolumn{2}{|c|}{$\begin{array}{c}\text { Women } \\
1994+ \\
-1 \text { year } \\
\end{array}$} & \multicolumn{2}{|c|}{$\begin{array}{l}\text { Men past } \\
3 \text { years }\end{array}$} & \multicolumn{2}{|c|}{$\begin{array}{l}\text { Women past } \\
3 \text { years }\end{array}$} \\
\hline & $\mathbf{N}$ & $\%$ & $\mathbf{N}$ & $\%$ & & $\mathbf{N}$ & $\%$ & $\mathbf{N}$ & $\%$ & $\mathbf{N}$ & $\%$ & $\mathbf{N}$ & $\%$ \\
\hline 1. Imprisoned, kidnapped, held captive & 69 & 15.7 & 25 & 5.2 & $<0.001$ & 3 & 0.7 & 5 & 1.0 & 21 & 4.8 & 6 & 1.3 \\
\hline $\begin{array}{l}\text { 2. Been a refugee, forced to flee from home to escape } \\
\text { danger/persecution }\end{array}$ & 96 & 21.8 & 132 & 27.7 & 0.055 & 56 & 12.7 & 64 & 13.4 & 4 & 0.9 & 5 & 1.0 \\
\hline 3. Experienced forced separation from family members & 19 & 4.3 & 35 & 7.3 & 0.122 & 6 & 1.4 & 12 & 2.5 & 1 & 0.2 & 2 & 0.4 \\
\hline 4. Experienced a life-threatening injury & 80 & 18.2 & 53 & 11.1 & 0.001 & 13 & 3.0 & 16 & 3.4 & 14 & $3.2^{*}$ & 5 & $1.0^{*}$ \\
\hline $\begin{array}{l}\text { 5. Experienced a murder or unnatural death of a family } \\
\text { member or a friend }\end{array}$ & 99 & 22.5 & 124 & 26.0 & 0.248 & 37 & 8.4 & 47 & 9.9 & 10 & 2.3 & 9 & 1.9 \\
\hline 6. Robbed, mugged, threatened with a weapon & 75 & 17.0 & 82 & 17.2 & 0.930 & 10 & 2.3 & 21 & 4.4 & 14 & 3.2 & 16 & 3.4 \\
\hline 7. Experienced imprisonment of close family member & 206 & 46.8 & 248 & 52.0 & 0.129 & 39 & 8.9 & 35 & 7.3 & 26 & 5.9 & 29 & 6.1 \\
\hline 8. Witnessed a traumatic event to a loved one & 136 & 30.9 & 170 & 35.6 & 0.093 & 17 & 3.9 & 24 & 5.0 & 29 & 6.6 & 30 & 6.3 \\
\hline 9. Ever been raped by a stranger & 5 & 1.1 & 17 & 3.6 & 0.011 & 1 & 0.2 & 1 & 0.2 & 0 & 0 & 1 & 0.2 \\
\hline $\begin{array}{l}\text { 10. Ever felt forced to have sex in exchange of money or } \\
\text { other benefits? }\end{array}$ & 6 & 1.4 & 25 & 5.2 & 0.001 & 0 & 0.0 & 1 & 0.2 & 3 & 0.7 & 2 & 0.4 \\
\hline 11. Witnessed repeated violence between family members & 25 & 5.7 & 49 & 10.3 & 0.011 & 7 & 1.6 & 6 & 1.3 & 4 & 0.9 & 7 & 1.5 \\
\hline $\begin{array}{l}\text { 12. Witnessed physical/sexual violence against a family } \\
\text { member by someone outside of the family }\end{array}$ & 18 & 4.1 & 36 & 7.5 & 0.034 & 3 & 0.7 & 6 & 1.3 & 3 & 0.7 & 8 & 1.7 \\
\hline 13. Witnessed someone being badly injured or killed & 43 & 9.8 & 88 & 18.4 & $<0.001$ & 14 & $3.2^{* *}$ & 36 & $7.5^{* *}$ & 5 & 1.1 & 5 & 1.0 \\
\hline 14. Witnessed atrocities, e.g. mass killings, mutilated bodies & 88 & 20.0 & 73 & 15.3 & 0.083 & 62 & $14.1^{* *}$ & 38 & $8.0^{* *}$ & 1 & 0.2 & 4 & 0.8 \\
\hline 15. Been in a combat situation & 56 & 12.7 & 58 & 12.2 & 0.765 & 16 & 3.6 & 16 & 3.4 & 10 & 2.3 & 10 & 2.1 \\
\hline 16. Any other life threatening or disturbing event & 74 & 16.8 & 83 & 17.4 & 0.860 & 29 & 6.6 & 29 & 6.1 & 12 & 2.7 & 8 & 1.7 \\
\hline Summary measure of all traumatic events & 323 & 73.4 & 399 & 83.6 & 0.132 & 165 & 37.5 & 169 & 35.4 & 110 & 25.0 & 110 & 23.1 \\
\hline
\end{tabular}

${ }^{*} \mathrm{P}<0.05 ;{ }^{* *} \mathrm{p}<0.005$.

$\mathrm{N}=917$, men 440; women 477.

Over the lifetime with similar trends during the genocide, women were more exposed to rape, forced sex, and having to witness repeated violence between family members but also to violence exercised by individuals outside of the family. Men were more exposed to mass-killings than women.

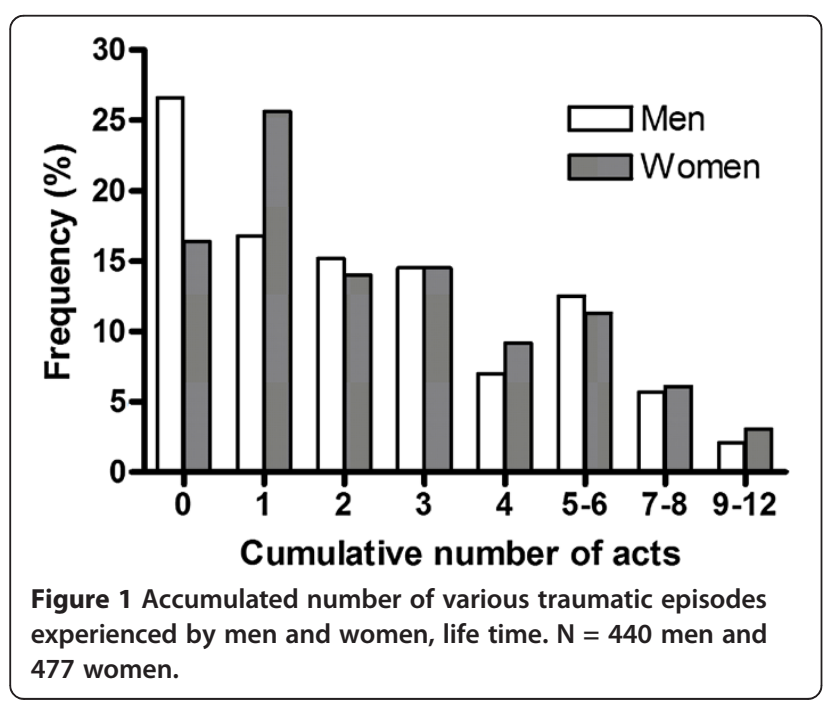

Finally, we found indications of how such traumatic episodes may influence future life circumstances as those exposed, both men and women, to a higher extent were low educated, had no children although being married and had low personal incomes compared to those not exposed. For both men and women these effects signal insecurity about the future and psychological distress.

\section{Findings in relation to other studies}

There is a sharp contrast between our findings and those of Neugebauer et. al., as in their study the prevalence for all kinds of traumatic episodes during the genocide is considerably higher, but their study collected its data in 1995 [10]. The respondents were school children aged 8-19 at the time, with fresh memories of the horrors taking place in the previous year. The age span is about the same in the two studies but 16 years have elapsed between the two data collections and the instruments used for obtaining the data were different. The difference in prevalence is most probably also explained by the fact that in our study, the youngest age group was only three to six years when the genocide occurred and these individuals may not have detailed memories of what occurred to be able to report on specific episodes. 
Table 5 Associations between traumatic episodes and socio-demographic and psychosocial factors for men and women in the period $1994 \pm 1$ year, presented as crude odds ratios and 95\% confidence intervals (Crude OR; $\mathrm{Cl} 95 \%$ )

\begin{tabular}{|c|c|c|c|c|}
\hline \multirow{2}{*}{$\begin{array}{l}\text { Variables } \\
\text { Respondent characteristicS }\end{array}$} & \multicolumn{2}{|r|}{ Men } & \multicolumn{2}{|c|}{ Women } \\
\hline & n (\%) & OR $(95 \% \mathrm{Cl})$ & n (\%) & OR (95\% Cl) \\
\hline \multicolumn{5}{|l|}{ Age groups } \\
\hline $20-29$ & $97(33.2)$ & 1 & $94(33.2)$ & 1 \\
\hline $30-35$ & $68(46.6)$ & $1.76(1.17-2.63)$ & $75(40.1)$ & $1.35(0.92-1.98)$ \\
\hline \multicolumn{5}{|l|}{ Marital status } \\
\hline Married or cohabiting & $95(40.3)$ & 1 & $135(39.5)$ & 1 \\
\hline Single, separated or divorced & $69(34.0)$ & $0.76(0.52-1.13)$ & $34(26.0)$ & $0.54(0.34-0.84)$ \\
\hline \multicolumn{5}{|l|}{ Number of children } \\
\hline Have children & $97(42.5)$ & 1 & $145(38.2)$ & 1 \\
\hline Have no children & $67(31.8)$ & $1.59(1.08-2.36)$ & $24(25.0)$ & $1.86(1.11-3.08)$ \\
\hline \multicolumn{5}{|l|}{ Ever attended school } \\
\hline Attended school & $149(40.4)$ & 1 & $137(34.9)$ & 1 \\
\hline Never attended school & $15(21.7)$ & $0.41(0.22-0.76)$ & $32(38.1)$ & $1.15(0.70-1.88)$ \\
\hline \multicolumn{5}{|l|}{ Level of education } \\
\hline Completed primary, vocational training, secondary school and university level & $68(43.6)$ & 1 & $61(42.4)$ & 1 \\
\hline Incomplete primary \& no school & $96(34.5)$ & $1.47(0.98-2.19)$ & $107(32.3)$ & $1.54(1.03-2.30)$ \\
\hline \multicolumn{5}{|l|}{ Employment status } \\
\hline Employed & $33(37.5)$ & 1 & $24(52.2)$ & 1 \\
\hline Not employed & $131(37.6)$ & $0.99(0.61-1.61)$ & $145(33.6)$ & $2.15(1.17-3.97)$ \\
\hline \multicolumn{5}{|l|}{ Personal Income } \\
\hline$>17500$ (greater than) & $139(36.4)$ & 1 & $150(33.7)$ & 1 \\
\hline$<17500$ RF (less than) & $26(47.3)$ & $1.56(0.89-2.77)$ & $17(56.7)$ & $2.57(1.22-5.44)$ \\
\hline \multicolumn{5}{|l|}{ Source of income } \\
\hline Salary, pension, disability grant or others & $33(35.9)$ & 1 & $20(46.5)$ & 1 \\
\hline No income & $131(37.8)$ & $1.08(0.67-1.75)$ & $140(33.3)$ & $0.57(0.30-1.08)$ \\
\hline \multicolumn{5}{|l|}{ Social support } \\
\hline Improved & $65(35.5)$ & 1 & $46(37.1)$ & 1 \\
\hline Poor & $100(38.9)$ & $1.16(0.78-1.71)$ & $123(34.8)$ & $0.91(0.59-1.39)$ \\
\hline \multicolumn{5}{|l|}{ Household characteristics } \\
\hline \multicolumn{5}{|l|}{ Household monthly income } \\
\hline Household income $>=17500 \mathrm{RF} /$ month & $33(38.4$ & 1 & $44(42.7)$ & 1 \\
\hline Household income $<17500$ RF & $126(37.8)$ & $0.98(0.60-1.59)$ & $123(34.1)$ & $0.69(0.44-1.09)$ \\
\hline \multicolumn{5}{|l|}{ Living standards } \\
\hline Improved; At least one improvement & $150(41.0)$ & 1 & $106(34.6)$ & 1 \\
\hline Poor; No improvements out of five & $15(20.3)$ & $0.37(0.20-0.67)$ & $63(36.6)$ & $1.09(0.74-1.60)$ \\
\hline \multicolumn{5}{|l|}{ Assets in the household } \\
\hline Improved; at least one of the items & $117(36.2)$ & 1 & $118(35.6)$ & 1 \\
\hline Poor; Have none of the items & $48(41.0)$ & $1.23(0.80-1.89)$ & $51(34.9)$ & $0.97(0.64-1.46)$ \\
\hline
\end{tabular}

Those of our respondents that belonged to the higher age groups were more exposed than the younger ones and as well more able to interpret situations and circumstances happening around them. Still, 16 years probably infers some problems with recalling certain events.

Another study investigated violence and trauma exposure about ten years after the genocide among 68 orphans, 13-23 years old [30] that had all been exposed to extreme levels of violence. Older youth (18-23 years) reported having witnessed a massacre more frequently than younger children, and more boys were victims of violent attacks than girls as was also found in our study. A smaller number also reported having experienced such events before and after the genocide, which is similar to our findings.

Finally, in a community-based study from 2010, i.e. performed 16 years after the genocide and one year before 
our study, exposure to various traumatic episodes were of about the same magnitude as in our study. However, mainly women were included and the sample size was rather small [31].

Not only recall bias including repression may be at hand as years elapse, there is also a risk of inability to remember events from childhood, as described by Felitti and co-workers in their studies on memory disturbances related to adverse childhood experiences (ACE). They investigated childhood autobiographical memory disturbance, which is a memory disruption characterized by the inability to remember events from childhood. Acts such as physical, sexual and emotional abuse, separation from parent/s, threatened or hurt by a knife or household member imprisoned were investigated [32]. They found in a population of 9460 men and women that $18 \%$ suffered from memory disturbances with a 4.4-fold risk increase for persons with $\geq 4$ ACEs. However, we cannot rule out whether this mechanism was relevant in our study but it might be the case especially for those exposed to accumulated traumatic episodes.

Women were, to higher extent than men, exposed to traumatic episodes in their lifetime, which may be explained by the fact that women more frequently than men are exposed to intimate partner violence over the life course [33]. In support of this assumption, the Rwandan Demographic and Health Survey from 2005 presented data for women's exposure to partner violence and show that $31 \%$ out of 4066 women were exposed to physical violence since the age of 15 , and $19 \%$ in the past year [34]. No published study is available presenting data on violence exposure in men. However, in another study within this project on intimate partner violence exposure we found that women were considerably more exposed to such violence than men [Umubyeyi A, Mogren I, Ntaganira J, Krantz G: Intimate partner violence directed at young men and women in post-genocide Rwanda: Prevalence and risk factors, Submitted. 2013].

No scientific studies have investigated on-going traumatic episodes in Rwanda. However it is obvious from our study on past three year prevalence that such violence and traumatic episodes are still on-going and should possibly be understood as the aftermath of the genocide. People are in fear when genocide perpetrators return to their villages.

The long-term effects observed in this study are of interest and have not been reported previously. The fact that both men and women were at excess risk of poorer life circumstances and less educational achievements than those unexposed is maybe not of any surprise but demands societal efforts and support as these are young people with many years of productive life remaining. Among most serious outcomes is the childlessness in both men and women. A cautious interpretation is that this may indicate feelings of insecurity about the future accompanied by psychological distress in both men and women.

\section{Methodological considerations}

The selected age groups for this study included children as young as three years at the time of the genocide. This may give rise to underreporting of traumatic exposures among the youngest age group. Recall bias but also memory disturbances and repression may further have troubled our participants, leading to underreporting.

The retrospective nature of the Harvard Trauma Questionnaire, asking about age at episode, potentially predisposes recall bias. The traumatic episodes in the genocide period were therefore calculated as episodes occurring in the year $1994 \pm 1$ year. This procedure may have caused some over-estimation. Evidence to support our choice of procedure is that the prevalence thus obtained is in line with what has been found in comparable studies [31].

The cross-sectional design allows for investigating long-term psychosocial effects of the traumatic episodes during the genocide period as these happened 17 years before the actual data collection, however, these findings are to be interpreted with some caution as this is not a true longitudinal study and recall bias may be at hand.

The procedure of randomly selecting the participants was done with great care, interviews were performed by trained clinical psychologists, and the non-response rate was negligible. The data collectors were health workers of a small age difference to the participants, which has been shown to improve the accuracy of the reporting in interviews [35]. As Rwanda is a small country with 10 million inhabitants [18], living under rather equal life circumstances, we believe that the findings of this study can be generalised to the entire population.

\section{Conclusion}

Seventeen years after the genocide, young men and women still carry memories of serious adverse experiences during childhood or adolescence. The violence is to a certain extent still on-going and some of the most commonly occurring episodes in the past three years are of the character that is not expected to occur in peaceful periods, such as being kidnapped or held captive and also violent deaths. Gender differences showed that while women were more exposed to traumatic episodes related to physical and sexual violence, men were to a greater extent exposed to imprisonment, kidnapping, mass killings or were badly injured.

Those exposed during the genocide period were also more likely to be childless although married, extremely low-educated and living under poorer circumstances 
than those not exposed. A cautious interpretation is that this may indicate feelings of insecurity about the future accompanied by psychological distress in both men and women. As this is a young population, societal efforts and support directed at young people with many years remaining of productive life are demanded. Health care services should be made aware of that extreme trauma has extensive long-lasting health effects and access to high quality care is of utmost importance.

\section{Competing interests}

The authors do declare that they have no competing interests whatsoever.

\section{Authors' contribution}

Gunilla Krantz (GK) designed the project in collaboration with Ingrid Mogren $(\mathrm{IM})$, developed the questionnaire and directed all steps of data collection in collaboration with IM and Joseph Ntaganira (JN). Lawrence Rugema (LR) supervised all the data collection from the field, supervised data entry and cleaning. RL carried out the statistical analyses with support from GK and IM. RL drafted the manuscript, GK, IM and JN read and revised the text until a final version, which was carefully read and accepted by all authors.

\section{Acknowledgement}

This study was made possible by a grant from the Swedish International Development Cooperation Agency (Sida) and by support from the National University of Rwanda, School of Public Health and the Department of Public Health and Community Medicine, Faculty of Health Sciences at University of Gothenburg, Sweden. We want to thank our data collectors for doing the job diligently and the participating men and women, who entrusted us with their private information

\section{Funding}

This study was supported by a grant from the Swedish international development cooperation agency (Sida).

\section{Author details}

'Department of Community Health, School of Public health, National University of Rwanda, Kigali, Rwanda. ${ }^{2}$ Department of Clinical Sciences, Obstetrics and Gynecology, Umeå University, Umeå, Sweden. ${ }^{3}$ Department of Public Health and Community Medicine, The Sahlgrenska Academy at Gothenburg University, Gothenburg, Sweden.

\section{Received: 8 September 2013 Accepted: 19 December 2013}

Published: 28 December 2013

\section{References}

1. Gourevitch P: We Wish to Inform you That Tomorrow we Will be Killed with our Families: Stories from Rwanda. New York: Farrar, Straus and Giroux; 1998.

2. Schaal S, Weierstall R, Dusingizemungu JP, Elbert T: Mental health 15 years after the killings in Rwanda: imprisoned perpetrators of the genocide against the Tutsi versus a community sample of survivors. J Trauma Stress 2012, 25(4):446-453.

3. Prunier G: The Rwanda Crisis: History of a Genocide. New York, NY: Columbia University Press; 2005.

4. Human Rights Watch. SHATTERED LIVES: Sexual Violence during the Rwandan Genocide and its Aftermath 2006. Retrieved May 28, 2013, from http://www.hrw.org/reports/1996/Rwanda.htm.

5. Cohen M, H. d'Adesky, A. C. Anastos K: Women in Rwanda: another world is possible. JAMA 2005, 294(5):613-615.

6. Donovan P: Rape and HIV/AIDS in Rwanda. Lancet 2002, 360(Suppl):17-18.

7. Zraly M, Nyirazinyoye L: Don't let the suffering make you fade away: an ethnographic study of resilience among survivors of genocide-rape in southern Rwanda. Social Sci Med 2010, 70(10):1656-1664.

8. Levers L, Kamanzi D, Mukamana D, Pells K, Bhusumane D: Addressing urgent community mental health needs in Rwanda: culturally sensitive training interventions. J Psychol Afr 2006, 2:261-272.

9. Wolters $\mathrm{S}$ : The gacaca process: eradicating the culture of impunity in Rwanda. Situation report by institute for security studies 2005 . Retrieved
May 22, 2013, from http://www.africaportal.org/dspace/articles/gacaca-processeradicating-culture-impunity-rwanda.

10. Neugebauer R, Fisher PW, Turner JB, Yamabe S, Sarsfield JA, Stehling-Ariza T: Post-traumatic stress reactions among Rwandan children and adolescents in the early aftermath of genocide. Int J Epidemiol 2009, 38(4):1033-1045.

11. Dyregrov A, Gupta L, Gjestad R, Mukanoheli E: Trauma exposure and psychological reactions to genocide among Rwandan children. I trauma Stress 2000, 13(1):3-21.

12. The Republic of Rwanda: National Unity and Reconciliation Commission: An Opinion Survey Results 2005-2007. Kigali Rwanda; 2008. http://www.nurc.gov. rw/index.php?id=70.

13. Pham PN, Weinstein HM, Longman T: Trauma and PTSD symptoms in Rwanda: implications for attitudes toward justice and reconciliation. JAMA 2004, 292(5):602-612.

14. Des Forges A: Leave None to Tell the Story: Genocide in Rwanda. New York, NY: Human Rights Watch. http://www.hrw.org/reports/pdfs/r/rwanda/rwanda993.pdf.

15. The Penal Reform International on Rwanda: The contribution of the Gacaca jurisdictions to resolving cases arising from the genocide Contributions, limitations and expectations of the post-Gacaca phase 2010. http://www. penalreform.org/wp-content/uploads/2013/06/Gacaca_final_2010_en.pdf.

16. Ministry of Local Government: Joint governance assessment report. The JGA report endorsed by cabinet 2008. http://www.afdb.org/fileadmin/uploads/ afdb/Documents/Project-and-Operations/ADF-BD-IF-2008-220-EN-RWANDAJOINT-GOVERNANCE-ASSESSMENT-JGA.PDF.

17. Republic of Rwanda: Ministry of Education Rwanda Statistics. Kigali, Rwanda; 2012 http://www.mineduc.gov.rw/MG/pdf/2011_RWANDA_EDUCATION_STATISTICS.pdf.

18. Demographic and Health Survey 2010: National Institute of Statistics of Rwanda. Kigali, Rwanda: Ministry of Health. Accessed May 25, 2013 from www.measuredhs.com/pubs/pdf/PR7/PR7.pdf.

19. The Republic of Rwanda: Matrimonial Regimes liberalities and successions, Law/no 22/99 of 12/11/1999. 2009. http://www.migeprof.gov.rw/MG/pdf/ MATRIMONIAL_REGIMES_LIBERALITIES_AND_SUCCESSIONS-2.pdf.

20. Ministry of justice: the Constitution of the Republic of Rwanda, Sub section 3 article 82. Retrieved May 25, 2013, 2013 www.rwandahope.com/ constitution.pdf.

21. Ghosh P: Rwanda: The Only Government in the World Dominated by Women. International Business times; 2012. http://www.ibtimes.com/rwanda-onlygovernment-world-dominated-women-213623.

22. Bolton P, Neugebauer R, Ndogoni L: Prevalence of depression in rural Rwanda based on symptom and functional criteria. J Nerv Mental Dis 2002, 190(9):631-637.

23. de Fouchier C, Blanchet A, Hopkins W, Bui E, Ait-Aoudia M, Jehel L: Validation of a french adaptation of the Harvard trauma questionnaire among torture survivors from sub-Saharan African countries. Eur J Psychotraumatol 2012, 10(3):3402-19225.

24. Oruc L, Kapetanovic A, Pojskic N, Miley K, Forstbauer S, Mollica RF, et al: Screening for PTSD and depression in Bosnia and Herzegovina: validating the Harvard trauma questionnaire and the Hopkins symptom checklist. Int J Cult Ment Health 2008, 1(2):105-116.

25. Mollica R, Caspi-Yavin Y, Bollini P, Truong T, Tor S, Lavelle J: The harvard trauma questionnaire. Validating a cross-cultural instrument for measuring torture, trauma, and posttraumatic stress disorder in Indochinese refugees. J Nerv Ment Dis 1992, 180(2):111-116.

26. Shoeb $\mathrm{M}$, Weinstein $\mathrm{H}$, Mollica R: The Harvard trauma questionnaire: adapting a cross-cultural instrument for measuring torture, trauma and posttraumatic stress disorder in Iraqi refugees. Int J Soc Psychiatry 2007, 53(5):447-463.

27. Fadnes LT, A Tylleskär, T: How to identify information bias due to self-reporting in epidemiological research. Int J Epidemiol 2009, 7:2

28. Smith D: The psychocultural roots of genocide: legitimacy and crisis in Rwanda. Am Psychol 1998, 53(7):743-753.

29. Human Rights Watch: Justice Compromised. New York: The Legacy of Rwanda's Community-Based Gacaca Courts; 2011.

30. Schaal S, Elbert T: Ten years after the genocide: trauma confrontation and posttraumatic stress in Rwandan adolescents. J Trauma Stress 2006, 19(1):95-105.

31. Rieder H, Elbert T: Rwanda - lasting imprints of a genocide: trauma, mental health and psychosocial conditions in survivors, former prisoners and their children Confl and. Health 2013, 7(1):6.

32. Brown DW, Anda RF, Edwards VJ, Felitti VJ, Dube SR, Giles WH: Adverse childhood experiences and childhood autobiographical memory disturbance. Child Abuse Negl 2007, 31(9):961-969. 
33. Braaf R, Meyering I: The Gender Debate in Domestic Violence: The Role of Data. Australian Domestic and Family Violence Clearinghouse. Sydney: The University of New South Wales; 2013. Issue paper 25, May 1-23.

34. Demographic and Health Survey 2005: National Institute of Statistics. Kigali, Rwanda: Ministry of Health; 2005. Accessed April, 2013 from http://www. measuredhs.com/publications/publication-FR183-DHS-Final-Reports.ffm.

35. Guest G, Bunce A, Johnson L, Akumatey B, Adeokun L: Fear, hope and social desirability bias among women at high risk for HIV in West Africa. J Fam Plann Reprod Health Care 2005, 31(4):285-287.

doi:10.1186/1471-2458-13-1235

Cite this article as: Rugema et al.: Traumatic episodes experienced

during the genocide period in Rwanda influence life circumstances in young men and women 17 years later. BMC Public Health 2013 13:1235.

\section{Submit your next manuscript to BioMed Central and take full advantage of:}

- Convenient online submission

- Thorough peer review

- No space constraints or color figure charges

- Immediate publication on acceptance

- Inclusion in PubMed, CAS, Scopus and Google Scholar

- Research which is freely available for redistribution 